\title{
The Reign Of Incurable Madness
}

\author{
X.I. Selene
}

\section{Le règne de la folie incurable}

Jane Hale découvre qu' elle est une FOLLE INCURABLE. Dans cet exposé de X.I. Selene sur l'appropriation et/ou les motifs ultérieurs sournois de la croissance personnelle et le désir corporatif de gérer ses ressources humaines et autres, Jane s'embourbe dans des tactiques de croissance personnelle, quelques unes pieuses, d'autres sans danger, $d^{\prime}$ 'autres soutenables, et d'autres sans espoir. Les massages thérapeutiques, les huiles, les suppléments alimentaires, et les interventions psychiatriques ne font rien pour soulager ses crises de larmes, ou la souffrance qui en découle. En marchant pour aller travailler, elle entend un train siffler: cela provoque une épiphanie qui la conduit vers une prise de pouvoir personnelle. À travers son instigation de et sa participation dans le violent renversement et la perturbation de la station de train, elle surpasse ses crises d'hystérie et découvre un dictionnaire alternatif et ironique sur la terminologie de la croissance personnelle.

\section{What Is "Self-Help"?}

Where you see "self-help," read "auto-reinstalling consumer adaptation." Self-help is strictly antithetical to massive societal change because it is the "self" which must be helped into the embrace of Power's full-body corset, a corset made with wires of Constraint, Hierarchy, Isolation, Mediation, Separation and Humiliation. Self-help is the process whereby individuals accept the terms of Power and learn to live under them. This is why the humanist defenders of the status quo say that a successful product of self-help has become "empowered."

But what is Power? It is just that social organization whereby masters maintain the conditions of slavery. Do not think for a moment that where Power surfaces, domination, exploitation and / or organization don't surface also. To become empowered is to ingest Power's ideology, to become a subdivided, Cartesian microcosm of the 
Power exhibited in full spectacular force.

\section{Case Study}

Jane Hale, 26, worked forty hours each week as a craft shop clerk. Diligent, punctual and courteous, she pleased her boss and customers. However, every month or so a terrible crying hysterical fit would overtake her, often for days. The insomnia, shortness of breath, chest pains, migraine headaches and exhaustion which inevitably accompanied these fits legitimized her sick days somewhat, but finally, afraid that she would lose her job, Jane Hale sought the services of a professional psychoanalytic counselor.

The psychologist analyzed Jane's early childhood experiences and experimented with a grab-bag of calming techniques, often recommending Jane the original self-help sources. Jane read widely and followed their instruction as best she could. In her psychoanalytic sessions she was able to exhibit a perfect poise and lucidity, gaining many insights about what could be causing her troubles.

Still, the hysterical crying fits continued without any decrease in frequency or intensity. She reassured her employer that she was seeking treatment, but the next week broke off her psychotherapy counselling in frustration.

Acting upon recommendations from books and acquaintances and upon her own desperation, Jane bought relaxing herbs, inhaled essential oils, took up creative dance, visited a massage therapist, took a women's journal-writing course at the Faculty of Extension, purchased a full spectrum lamp, masturbated regularly, experimented with veganism briefly, and began a regimen of morning stretching. Some of these self-treatments Jane applied for months; others she dropped out of a kind of embarrassment over their piety.

But perhaps because Jane Hale secretly felt that each of these treatments bore the stigma of fadism or perhaps because Jane Hale didn't want to be converted to any religion, ultimately nothing "worked." She still found herself in the clutches of unstoppable, terrorizing emotions.

One morning, passing a few blocks from the rail yards on her way to work, Jane Hale heard a train whistle, disconcertingly out of tune. Startled, she looked up to find a co-worker, also on her way to work, responding to the same sound. Jane Hale spontaneously imagined an 
orchestra composed of trains and their badly-tuned whistles. She had an irresistibly strong desire to create that orchestra. So inspired, she could not conceal her imagining from her co-worker.

So the two set off to the rail yard immediately, set fire to box cars, hi-jacked an engine, rallied the rail workers and so began their train engine orchestra. The wildcat strike thus descended, the workers occupied the rail yards for three months, holding impromptu concerts consisting of all dimensions of train noise. Jane Hale did not have a single attack of uncontrollable sobbing in this time.

Jane Hale knew she was INCURABLY MAD.

\section{Self-Help Vocabulary and Translations}

child within, inner child

empowerment

healing

inner child

power

recovery

self

self-discovery

self-help eternal-powerlessness generator

the process of ingesting Power's ideology; succumbing to self-help

learning to love repression

see child within

social organization whereby masters

maintain the conditions of slavery

recuperation; revolutionary tactics are

cleansed of their subversive intents and used to further the hold of Dead Time World

irreducible core of pure consuming potential

creation of a matrix whereby one can minimize "negative emotions" by maximizing consumption. example: decreasing the number of crying outbursts by taking an expensive relaxation course auto-reinstalling consumer adaptation 